\title{
The Global Economic Hibernation: Macroeconomic Indicators and Health Management Policies
}

\author{
Küresel Kış Uykusu: Makroekonomik Göstergeler ve Sağlık Yönetimi Politikaları
}

\author{
Nigar DEMIRCAN ÇAKAR ${ }^{1}$ \\ (1) 0000-0002-7878-9123 \\ Ayfer GEDIKL $\dot{I}^{2}$ \\ (D) 0000-0002-7128-1976 \\ Seyfettin ERDOĞAN ${ }^{3}$ \\ (1) 0000-0003-2790-4221
}

\begin{abstract}
Considering its dire effects on different sectors, the coronavirus is far more than a health problem. The pandemic has hit the global economy starting with the developed world and now spreading into emerging economies. It is a fact that developing countries are more disadvantageous in this process since not only their health conditions and health services are not so sophisticated as their developed counterparts, but also macroeconomic conditions are not strong enough to endure such a long-lasting socio-economic crisis. Those countries are poorer and it is hard for them to allocate sources to the health sector. Comparing with emerging economies, the developed world also has been suffering from the severe effects of the pandemic. Because of long-lasting lock-down and contractions in the global economy, all developed economies revealed negative economic growth rates for the proceeding years. The purpose of this article is not only to compare the macroeconomic effects of the coronavirus disease 2019 (COVID-19) pandemic on developed and developing countries but also to assist economy authorities, health care leaders, and their organizations in anticipating and preempting problems by providing alternative health management policies rather than reacting. Macroeconomic variables data that are released by the World Bank and IMF will be applied to make the comparisons.
\end{abstract}

Keywords: COVID-19; developed countries; developing countries; macroeconomic performance; health management.

öz

Koronavirüs pandemisinin farklı sektörler üzerinde yarattığı korkunç etkiler göz önüne alındığında, salgının küresel bir sağlık sorunu olmanın çok ötesinde girift ve çok katmanlı sorunlar doğurduğunu ifade etmek yanlış olmayacaktır. Öncelikle gelişmiş ülkelerde başlayan pandemi, alınan tüm küresel tedbirlere rağmen hızla gelişmekte olan ülkelerde de yayılmaya başlamıştır. Olumsuz etkileri uzun yıllara yayılacağı belli olan bu salgınla mücadele konusunda gelişmekte olan ülkeler gerek sağlık hizmetleri arzı ve sağlık altyapısındaki yetersizlikler, gerekse yerel ekonomilerin makroekonomik koşullarındaki kırılganlıklar nedeniyle gelişmiş ülkelere göre oldukça dezavantajlı durumdadırlar. Bu ülkeler, kaynak yetersizliği nedeniyle, sağlık harcamalarındaki artışı karşılayacak ekstra fonlara da sahip değildir. Gelişmekte olan ülkelerdeki bu ağır durum yanında, gelişmiş ülkeler de pandemi sürecinde darbe almış ve peş peşe açılanan negatif büyüme oranları ile vahim tablo daha da netleşmiştir. Pandeminin etkilerinin uzun yıllara yayılması beklendiğinden, negatif büyüme oranlarının daha birkaç yıl devam edeceği tahmin edilmektedir. Bu çerçevede bu çalışmada koronavirüs hastalığı 2019 (coronavirus disease 2019, COVID-19) pandemisinin makoekonomik etkileri gelişmiş ve gelişmekte olan ülkeler ayrımı ile analiz edilecek ve sağlık kurumları yöneticilerinin istifadesine sunmak üzere sağlık yönetimi politika önerileri getirilecektir. Ayrıca, derinlemesine bir litaratür incelemesi yanında, Dünya Bankası ve IMF gibi küresel kuruluşlar tarafından açıklanan verilerin mukayeseli olarak ele alınacağı çalışmada, pandeminin yerel ekonomiler üzerindeki olumsuz etkilerinin en aza indirilebilmesi doğrultusunda mevcut durum ve alternatif politika önerileri de sunulacaktır.

Anahtar kelimeler: COVID-19; gelişmiş ülkeler; gelişmekte olan ülkeler; makroekonomik performans; sağlık yönetimi. 


\section{INTRODUCTION}

With its unprecedented dimensions, the coronavirus disease 2019 (COVID-19) pandemic has immensely impacted both social and economic life around the globe. Actually, the outbreak created first the purely medical shocks, then the adverse economic impacts due to containment measures, and third the expectations shock which led people all over the globe to wait-and-see mode (1). With the lockdown precautions, patients could not go to hospitals and could not get required medical services either due to fear of pandemic spread, or lack of health services because of excessive healthcare service for corona patients. Furthermore, economic turmoil following the lockdown has reduced insurance coverage and the willingness and ability of households to pay for health care (2).

When the pandemic was come to the light, the first precaution of the governments was to protect the health and safety of their citizens. Therefore, great lockdowns were immediately initiated all over the world. Once the pandemic started to spread, internet technologies were highly used in all sectors, and the health sector had no exception. Internet-connected medical devices have been developed and widely used. Workers from different sectors and particularly medical sector staff had to use those technological instruments. Stand-alone technologies were digitalized and integrated with other systems. Besides, there was a rapid shift to entirely remote work to limit the spread of the pandemic. However, these precautions could neither take the pandemic under control nor has it been supported to protect the local macroeconomic conditions. However, as the process continued, deep economic problems came forth. In front of the governments, there was a trade-off: Either they would continue the lockdown and control the spread of the pandemic, or ease the controls and re-open the economic activities but take the risk of spread. While macroeconomic conditions have been deteriorating due to the great lockdown and the pandemic, the continuous increase in health expenditures and the inability to develop a concrete drug or medication model for the treatment of the disease left countries in a very difficult situation. Indeed, because of the strong health measures and economic lockdown, the global economy went to a long-lasting hibernation. Economic activities dropped dramatically all over the world. For example, economic activities fell around $1 / 3$ in the EU overnight. No doubt that the ultimate damage of the pandemic to societies and economies would be much greater than the initial impact. (3).

It is a fact that COVID-19 triggered a global economic crisis due to the sudden stop which resulted in a depression. No doubt that the current depression is deeper than the recession of the global financial crisis in 2008. On her live webinar speech, ECB President Christine Lagarde (4) warned that the sudden stop of economic activities caused by the pandemic triggered a recession twice as deep as after the 2008 Global financial crisis, and GDP is expected to shrink by 8 to $12 \%$ in the Euro Zone in 2020 . She described the current recession as "a massive economic crisis and one that was literally unheard of in peacetime for the damage it is causing". Similarly, IMF (5) describes the current economic crisis due to the COVID-19 pandemic as "the crisis like no others" and the worst recession since the Great Depression. According to
IMF (5), the world GDP growth declined to $-17.8 \%$ in 2020 , from $4 \%$ in 2019 . The current crisis had devastating effects on people's lives. In addition to the loss of lives, people lost their jobs; many people worry about how to pay rent and bills; because of the increasing number of patients, it becomes harder to get healthcare services. In other words, COVID-19 increased the fragility of health systems. During the pandemic period, the weaknesses of local economies can be summarized as follows (6):

- Shut-down or not: A critical trade-off is either keeping the economy working or going to shut-down. Supporters of "economic activities should go on" asked a very critical question of "if the economy is shot-down, what can the government finance the healthcare expenditures". A supporter of the economic shut-down answered this question as "if we cannot take the outbreak under control, more and more people die, it will be more costly and the pandemic may continue many years with millions of people loss.

- Spending priorities: The pandemic crisis brought tradeoff policies. On what should money be spent, how the budget should be executed, what is the balance between spending on primary healthcare and tertiary health sector and spending on health or other services that condition health outcomes are some of the trade-offs.

- Lack of equity: There is a great economic gap between developed and developing countries. While the developed countries may provide lab services for testing and health services for treatment, less developed countries may difficulty in providing these services. Even within the developing countries, richer people can get health services through the private sector whereas poor people have to wait for the government to provide tests/vaccination or work under risky conditions.

- Left-behind groups: Not only for social justice but also for controlling the disease, left-behind groups cannot be ignored. Vulnerabilities such as age, gender, homelessness, economic insecurity, unemployment are the basis for critical factors affecting the seriousness of the spread of the disease.

- Links between the health sector and others: COVID-19 pandemic affected the other sectors as well. Millions of children cannot go to school due to the pandemic and the education sector had to find alternative models with distance education. Similar devastating effects can be observed in the tourism and aviation sectors.

Due to the suddenness of precautions and measures, i.e. economic downturn, the impacts of the COVID-19 on the local economies are visible and traceable. It is not a surprise that the measures taken to solve the health crisis and economic shutdown would threaten the macroeconomic performances of the countries. It is a fact that there is a great financial burden in both advanced and emerging economies because of the current outbreak. The challenges have great impacts even on many nations with high income and well-developed health systems which indicates how deeply it may impact developing and lessdeveloped countries with poor macroeconomic conditions and fragmented health systems. The weak macroeconomic structure of developing countries exacerbated the financial pressure on them. 
Figure 1 illustrates the channels of economic impacts of the COVID-19 pandemic. According to Figure 1, there are health threats on one side. On the other side, there are economic, social, and administrative impacts that result in negative consequences on education, manufacturing, consumption, trade, and transport. These contractions cause less wage, unemployment, and exacerbating poverty with loss of human capital and infrastructure deterioration. The prevailing COVID-19 pandemic caused an increase in demand for health products and services even the bestresources health systems under acute stress. Many states have been suffering from a lack of resources. During the outbreak, partnering with the private sector could be a strategic solution. However, there are some challenges. For example, the private health sector lacks specific inputs needed to play an effective role; in the weak systems emergency legislation can limit the private sector; governments are unsure how best to include the private sector to provide health services; and private healthcare businesses faced with great financial losses during the pandemic, but governments could not support them in this process (8). In their research covering 12 low-and middleincome countries, Hellowell et al. (2) indicated that measures for flattening the curve caused a cash crunch for the private health sector. Those private health institutions had to scale back their businesses and even lay off health workers. Therefore, getting the support of the private sector may be hard for the government in fighting the outbreak.

In this context, the purpose of this study is to analyze the macroeconomic impacts of developing and developed countries suffering from the growing burden of COVID19. Since the pandemic is still prevailing, there is still a limited number of studies analyzing the macroeconomic impacts of the pandemic on developing and advanced economies. Being one of the pioneer studies in this field will be one of the contributions of this paper to the related literature. The rest of the paper covers first the literature survey. Then, we will explain the impacts of the pandemic on the global economy applying data from different sectors. In the last part, alternative policies to cope with the pandemic will be put forth.

\section{EVALUATIONS OF THE EFFECTS OF PANDEMIC}

In the literature, there are limited papers addressing the impacts of the COVID-19 pandemic on the local economies since the pandemic and its effects are not over, yet. Evans and Over (7) expressed that deteriorating macroeconomic conditions negatively affect the healthcare services in low- and middle-income developing economies; they suffer from the impacts of the pandemic more than the advanced economies. Besides, Sembene (9) indicated that a growing number of low-income African countries will suffer from unsustainable debt burdens due to deteriorating conditions of pandemic and its macroeconomic effects. Bohmer et al. (10) pointed the global shortages of crucial materials such as masks, ventilators, incentive care units (ICU), and the number of health workers during the pandemic. The authors explained that the shortages and supply constraints require initiating policies to address both the demand and supplyside roots of the pandemic. Gupta and Jalles (11) analyzed the budgetary impact of the pandemics including SARS, N1H1, MERS, Ebola, and Zika over 170 countries. The authors found a great impact on the budgets of all countries. They also found that the impacts of pandemics

\section{Channels of Economic Effects of Covid-19}

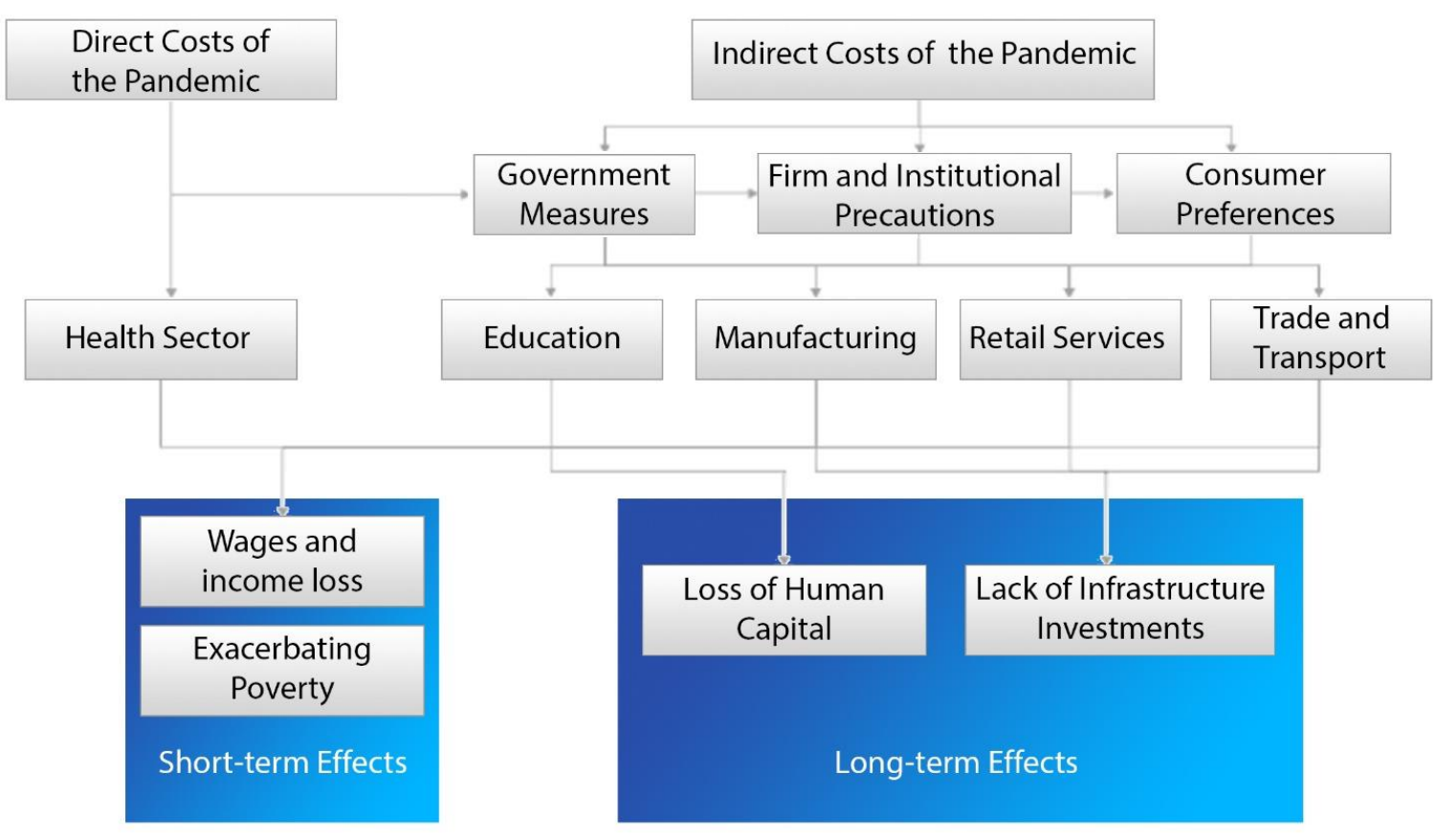

Figure 1. Channels of economic impacts of COVID-19 pandemic. Source: Evens and Over (7). 
are more substantial and effects are long-lasting in developing countries due to great falls in revenues. The effects are not enormous in developed countries where revenues are less affected but expenditures than in developing ones owing to the natural operation of automatic stabilizers. Tully et al. (12) investigated the financial measures introduced by the Italian government regarding investment projects for the production and supply of medical devices and personal protective equipment. As one of the developed countries, Italy could manage to provide support to different sectors. The financing covered the form of low-interest or zero-interest loans to cover up to $75 \%$ of the investment projects. Glassman (13) also explained the dramatic consequences of the pandemic on countries across the income spectrum. The author also pointed the social consequences of the pandemic and economic recession. Adams (14) searched the effects of the pandemic on the health insurance market. She indicated that insurance premiums jumped from $4 \%$ to $40 \%$. Cavallo (15) analyzed the impact of the COVID-19 pandemic on inflation rates in the US. The author found that the COVID19 had an increasing pressure on the official CPI and therefore the real inflation rate was found to be higher than the official one. He found a similar negative effect of the COVID-19 on 10 out of 16 selected countries.

\section{EFFECTS OF PANDEMIC ON GLOBAL ECONOMY}

The pandemic has caused both demand and supply shocks. On the demand side, income losses, fear of contagion, and increasing uncertainty led to less spending. There is also increasing unemployment as well as postponing salary payments. Declines in the spending of consumers have caused demand shock. The great shutdown lowered production and created a shock to supply as well. Furthermore, since the quarantine caused a drop in capacity utilization, there are greater impacts on economic activities. In addition, firms could not get the parts they need in the supply chain, whether domestically or internationally, and they could not continue their production processes even though they wanted to. For example, China is one of the greatest suppliers of intermediate goods, especially in electronics, automobiles, and machinery. The bottle-neck due to the disruption caused knock-on effects on downstream firms. All these negative effects resulted in negative productivity shocks that slowed-down economic activities (16).

Since the advanced economies and China, which represent $3 / 4$ of world output, were initially more affected by the pandemic, month-to-date analyzes of the COVID-19 outbreak have been heavily concentrated on these countries. Nevertheless, as $2 / 3$ of the world population lives in developing countries, the responses to the pandemic and current economic shock should also include actions for the developing world as well. There is increasing pressure on the developing countries' government budgets because of the public health expenditures. The social distance protections to control the spread of the pandemic caused the economic shutdown in both developed and emerging economies. In addition to the global economic problems in recent years, the lockdown policies due to the pandemic led to a great fall in employment rates. The advanced economies could manage this process by their strong administrative capacity and their fiscal power. Unfortunately, it was not the same for the developing countries. These countries had to experience contractions of incomes with falling fiscal revenues. Tighter fiscal space and a weak healthcare system brought a higher human and fiscal tradeoff with a dangerous vicious cycle for them. Furthermore, the necessity of crucial goods and services to fight the pandemic caused a further tightening in the balance of payments. (17).

The early precautions of government to the pandemic were banning the economic activities. For example, China shut down the factories, Italy closed the shops. Meanwhile, firms and schools took proactive measures to avoid infection due to government bans and business decisions. However, the result was low wages for workers, loss of jobs, less shopping, travel, and limited social activities. These measures impacted all sectors starting from the health sector, manufacturing, retail, trade and transportation, tourism, and education which reduced income both through the supply side (less production, higher prices for consumers) and the demand side (less demand, less production and sales, and higher unemployment). Those short-term economic impacts turn into a reduction in long-term economic growth. Due to excessive healthcare expenditures and fewer people's social activities, countries invest less in physical infrastructure. Similarly, as schools close, students learn less and cannot improve their knowledge in their field, and the result is reduced overall human capital for their economies. The negative impacts of the pandemic will be observed mostly in the least developed countries as well as low- and middle-income developing countries. Besides, the slowdown in the Chinese economy and reduced Chinese demand for raw materials will reduce investments in energy, mining, and related sectors. Less income in all sectors will increase the vulnerability in the travel and tourism sectors. Apart from poor African countries, 22 Asian countries including Maldives, Cambodia, and Thailand are seriously affected countries (7).

Figure 2 illustrates the annual world output percentage change over the period 2009-2021. 2020 and 2021 are estimated years. The selected period starts from 2009. In the wake of the Global Financial Crisis, there was a recovery period starting from 2010 . However, there was a steady negative trend in the global output growth until 2019. As shown in Figure 2, there is a sharp decline in output from the global shutdown. Figure 2 confirms that contraction will continue in 2021 as well. Numerically, world output growth is expected to decline by $4.3 \%$ in 2020 and $4.1 \%$ in 2021.

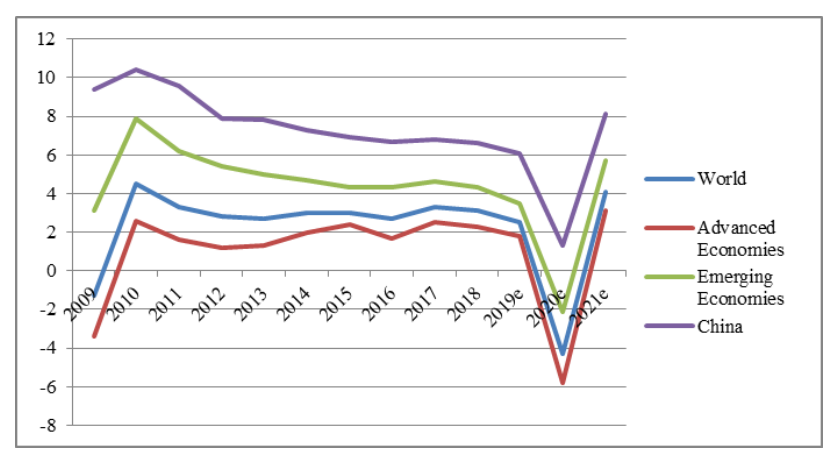

Figure 2. World output growth 2009-2021* (annual percentage change). Source: UNCTAD (17). *2020 and 2021 data are estimated 
According to Figure 2, both advanced and emerging economies will have historically bad economic performances. As one of the advanced regions, in the Euro area, GDP is expected to shrink by $20-25 \%$ in 2021 relative to the 2019 level. The debt/GDP ratio indebtedness is forecasted to rise by almost 50\% of GDP in 2021 (18).

\section{CURRENT ECONOMIC CONDITIONS OF ADVANCED AND DEVELOPING ECONOMIES}

COVID-19 is expected to have devastating effects on the developing and advanced European and Asian countries in different channels. The first channel is the trade and global value chains. Especially Central and Eastern European countries are highly integrated with the global trade through final goods, intermediate goods, and services. The second channel is commodity prices which are expected to affect the countries in Central Asia and Russia. The third channel is tourism since this sector is the most affected sector from both the demand and supply sides. This impact will negatively affect the less diversified countries whose economies are heavily dependent on the tourism sector as well as Turkey and the Caucasus. The fourth channel is financial and credit markets. Financial market volatility will impact the countries with vulnerable internal and external positions like Ukraine and Romania. The last channel is remittances. It is a fact that there are millions of refugees and immigrants. Western Balkans, South Caucasus, and Central Asia regions are expected to be affected the worst (19). Comparing with the other regions, the Middle East and North Africa had significant impacts of the pandemic which caused sharp declines in oil production, tourism, and remittances. Furthermore, fall in capital flows and disruptions in global value chains had dropped in domestic production in these regions. While oil-exporting countries had the greatest impact due to sharp declines in oil prices, oil-importing countries also had great GDP drops because of lack of investment and private consumption. What is more, although MENA countries have a great unemployment problem, these countries are expected to see higher unemployment rates. In the aforementioned region, the transportation sector is suffering; particularly aviation sector is deeply affected by the pandemic. The logistic sector of Morocco and Tunisia and the textile sector of Jordan are affected due to weakening international trade. Falling consumer demand reversely affected the wholesale, retail, and construction sectors (20).

In the following parts, the impact of the pandemic on different variables will be analyzed separately.

\section{Impacts on Economic Growth}

Economic growth dropped below its average in recent years in the Euro Area. While GDP growth was $0.2 \%$ in 2018-Q4, on the eve of the pandemic, it dropped to $0.1 \%$ in 2019-Q4 in the Euro Area (21). As illustrated in Figure 3 , before the COVID-19 pandemic, the average growth rate of the world economy was 3\% between 2017 and 2019. However, starting from 2020 with the emergence of the pandemic, there is a sharp decline in 2020. According to UNCTAD (17) baseline scenario, the world average growth rate will have a positive trend starting from 2021 and is expected to reach its 2019 value with $\$ 99,7$ trillion. The COVID-19 crisis will cause almost a $\$ 12$ trillion loss in global income by the end of 2021 (17).
Deteriorating macroeconomic conditions negatively affected the precautions against the pandemic, particularly in low-income developing countries. After a year in the crisis and uncertainty with the near future, the conditions brought great challenges in fighting the pandemic due to a lack of adequate financing (9). IMF provided financial support and policy anchor for the low-income countries to recover from the COVID-19 crisis. IMF initiated a $\$ 9$ billion Poverty Reduction and Growth Trust which was $\$ 1.5$ billion per year in the previous five years (22). To support the low-income countries, IMF also allocated the special drawing right (SDRs) have been made to provide additional liquidity to African poor countries in recent months. The issuance of $\$ 500$ billion of SDRs was called for by ministers of finance of African countries. This amount was distributed across countries, regions, and income groups (23).

\section{Impacts on Unemployment}

In many countries, although manufacturing and service sectors limited their activities, governments refrained from layoffs. According to ILO (24), full or partial lockdown due to the COVID-19 pandemic affected almost 2.7 billion workers which represent almost $81 \%$ of the global workforce. Besides, working hours declined by $6.7 \%$ in the second quarter of 2020 which equals 195 million full-time workers. Also, informal employment is more in hard-hit sectors in low and middle-income countries. The highest informal employment is in Africa with a rate $71.9 \%$. Arab states follow African countries with $63.9 \%$ informal employment. This brings loss of income and deeper poverty. Health workers, workers in transport, agriculture, and essential public service providers, workers in residential care facilities, laundry, and cleaning staff confront with serious risk of contacting COVID-19 in their workplace. Employees working in wholesale, manufacturing, real estate, transport, art, entertainment, and recreation sectors were the most affected workers. Following these sectors, agriculture, forestry, construction, financial and insurance, mining, and quarrying are the second most affected sectors from the pandemic (24). In European countries, despite the fact that there were limited productivity gains with above-inflation wage growth affected firms' profits. This strategy brought the firms to the limit of their capacity of labor hoarding. Following this fragility in the labor market, the COVID-19 outbreak and the following confinement measures taken by governments caused significant disruptions in labor markets (21). During the pandemic, many countries

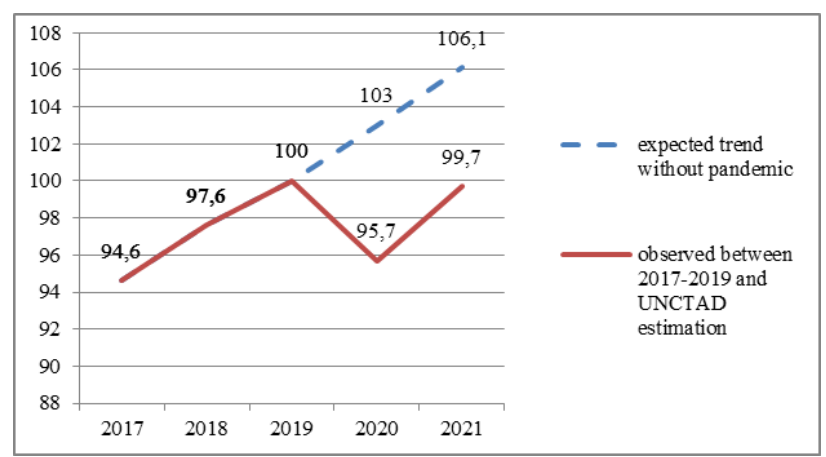

Figure 3. World output level, 2017-2021* (trillion \$). Source: UNCTAD (17). *2020 and 2021 data are estimated 
initiated business-cycle stimuli to prevent layoffs. Decreasing the labor costs and schemes to create public employment as well as short-term work became popular policies in the labor sector. Short-term work is a labormarket policy that subsidizes the firms to prevent layoffs (25). Besides, some countries initiated technological adoption and employment on it. Technology adoption and applying information technologies not only protect economies from the negative impact of a pandemic but also the unemployment rate increase less (26).

\section{Impacts on Inflation}

Because of the shutdown of many sectors and restructure operations, governments had great budget deficits to fund support programs during the pandemic. These problems are likely to cause inflationary or deflationary dynamics depending on the policies the governments initiate (27). For example, a sharp decline in demand for goods and services lowered inflation for many components of CPI in many countries. This situation brought a persistent lack of inflation. There will be practical challenges to measuring during the COVID-19 pandemic period (28). For developed countries, the low level of inflation caused easier monetary policy and quantitative easing programs. After the global financial crisis, in many countries, the inflation targeting strategy has been expanded. However, quantitative easing was introduced during the pandemic to alleviate the recession which may result in long-term inflation (29).

While there have been low rates of inflation in most of the developed economies, Erdoğan et al. (30) indicated that there is increasing pressure on the inflation rates due to increasing domestic money supply and exchange rate variables in developing economies over the pandemic period. The authors also pointed the spread of macroeconomic problems such as inflation to neighboring countries. In his study, Cavallo (15) confirms Erdoğan et al. (30)'s findings. The author indicated that the COVID19 inflation rate was higher than the official CPI in the US and there were similar findings for 10 out of 16 sample countries. He also indicated that consumers spend more on food and other related categories which push the inflation rates upward whereas transportation and related categories experienced significant deflation.

\section{Impacts on International Trade}

In the early months of the pandemic, advanced countries and China implemented a $\$ 1.4$ trillion stimulus. However, in spite of these supports, there were still sharp declines in economic growth rates of all countries. The negative growth rates will bring lower demand for exports for other developing countries. Sharp declines in energy and commodity prices are accompanying the export losses. Export losses will bring a fall in the foreign exchange earnings in developing countries. This will be an additional challenge to the national currency depreciation against the US dollar for these countries. The import contractions are estimated at $\$ 575$ billion (17).

Figure 4 and Figure 5 demonstrate the export and import volumes of the world and the country groups. Both figures confirm the consistent declines in both developed and developing country groups and the world as a whole. Among the developed county groups, the greatest drop in trade volume is observed in the Euro Area. While the year- on-year export rate changes were $1.9 \% ;-0.2 \%$ and $13.3 \%$ in 2018; 2019 and 2020 respectively, the year-on-year import volume changes were $2.2 \%$; $0 \%$ and $12.2 \%$ in the same period. On the contrary, although the COVID-19 pandemic first hit China, the country had a relatively moderate contraction. Year-on-year per cent export volume changes of China were $5.4 \%$; $0.5 \%$; and $-4.4 \%$ in 2018; 2019; and 2020. For the same period, the import rate changes were $6.9 \%$; $-0.4 \%$; and $-2 \%$ in China (17).

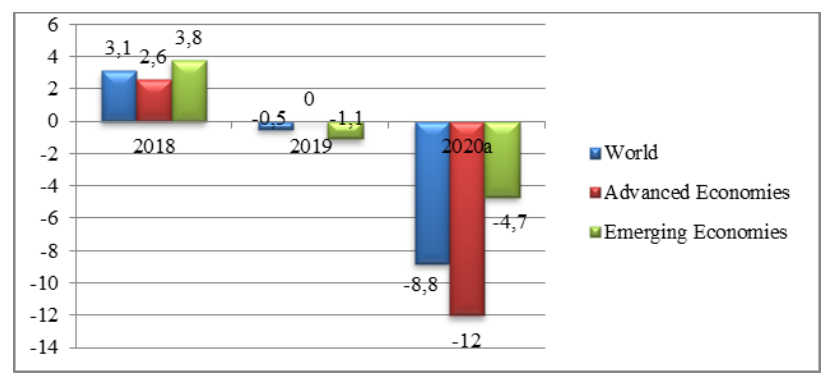

Figure 4. Export volumes of the World and country groups, 2018-2020* (\% change over the previous year). Source: UNCTAD (17). Advanced economies: Euro Area, the US, and Japan. Emerging economies: China, Asia (China exc.), Latin America, Africa, and Middle East. *2020 data are estimated

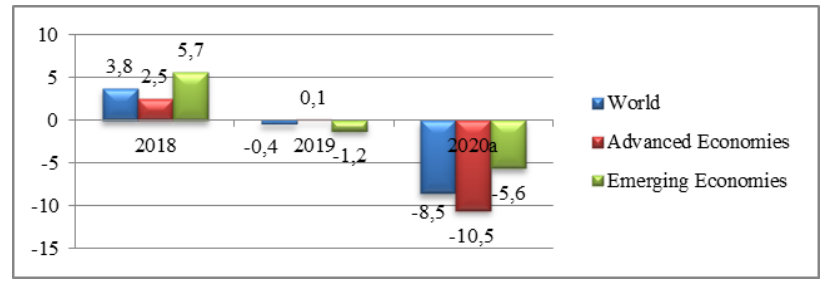

Figure 5. Import volumes of the World and country groups, 2018-2020* (\% change over previous year). Source: UNCTAD (17). Advanced economies: Euro Area, the US, and Japan. Emerging economies: China, Asia (China exc.), Latin America, Africa, and Middle East. *2020 data are estimated

\section{Impacts on the Financial Sector} COVID-19 pandemic affected the financial system through four channels (31):

- Market risk: Higher uncertainty with investor's insecurity together increase funding costs both in domestic and international markets for government and private sectors.

- Liquidity risk: Market volatility leads to higher demand for liquidity. Besides, sharp declines in cash flow affect firms and push public demand for cash that results in tightening funding and liquidity conditions for banks. This impacts lending to the private sector.

- Credit risk: Increasing nonperforming loans and costly lending cause loss of income.

- Risk of earning and resilience: The other risks weaken the earnings and profitability in the financial sector.

Because of the extraordinary conditions of the current pandemic, borrowing costs will rise and financial conditions will tighten since banks will be suspicious about the consumers' repayments of their loans. Higher borrowing costs will increase financial vulnerabilities. 
Credit cuts may amplify the downturn arising from the demand and supply shocks. Furthermore, the demand and supply shocks will dampen the global activity through decreasing international trade and financial linkages which will push the commodity prices down. Besides, oil prices have fallen $30 \%$ below their levels during the shutdown period, in addition to its fluctuations in the last three years. Reliance on external financing may be risky since they may stop suddenly. Disorderly market conditions also worsen the conditions. All these improvements may require foreign exchange intervention or capital flow measures (16).

\section{Impacts on Debt Vulnerability}

While the debt burden is very risky for developing countries, it is not thought to be a risk for the Euro Area. According to the ECB President Lagarde (4) although many Euro Zone countries are raising extra debt in response to the pandemic, this is sustainable due to lowinterest rates which made the costs manageable. She also added that the countries which have a better "fiscal space" will emerge from the pandemic. Therefore, the fiscal space and interest rate of the local country are very critical in debt sustainability and managing the pandemic period.

While the total external debt stocks of developing countries were $\$ 4,5$ trillion in 2009 , it reached $\$ 10$ trillion, a new record, by the end of 2019. The global financial ecosystem was very attractive for speculative investors with short-term policy-induced boosts which led to a growing inequality rather than a sustainable economic performance or recovery of aggregate demand. Lack of sufficient strong GDP growth in the emerging economies resulted in the rise of the average ratio of total external debt-to-GDP from $25 \%$ in 2009 to $29 \%$ in 2019 . If China is excluded, this figure reaches an average of $38 \%$ in 2019. Accumulating external debt absorbs the growing share of emerging countries. The ratio of total external debt-toexports increased to $111 \%$ in 2019 from $105 \%$ in 2018. Similarly, emerging countries spent $14.6 \%$ of their export revenues to meet external debt obligations while it was $7.8 \%$ in 2011. Furthermore, not only middle-income developing countries but also oil exporter countries hit by the recent oil price fluctuations had to transfer more than a quarter of government revenues to publicly guaranteed external debt in 2019. Besides, external debt positions became shorter maturities and higher roll-over risks. Numerically, the total short-term external debt share increased to $29 \%$ in 2019 while it was $20 \%$ in the first half of the 2000s. And also, due to the fell of the ratio of shortterm external debt-to-reserves to $279 \%$ in 2019 from $544 \%$ in 2009 , the ability to develop countries to self-insure against exogenous turbulences and market risk became more fragile position (17). Right after the negative impacts of COVID-19 were recognized, in April 2020, the World Bank and IMF made a call and the G20 endorsed to make Debt Service Suspension Initiative (DSSI) to help up to 73 of the poorest countries manage the impact of the COVID19 pandemic. The total external debt of those countries reached $9.5 \%$ and $\$ 744$ billion in 2019 from 2018 showing the growing risk of sovereign-debt crises due to the COVID-19 pandemic (32).

Remittances, profit output, and royalty payments may also bring financial difficulties to developing countries during the pandemic period. The outbreak also caused great capital outflows from emerging countries which triggered large currency depreciations vis-à-vis the lead currencies. The countries which have a high volume of foreign debt may have difficulty in debt sustainability. This leads to debt vulnerabilities in emerging countries. At the end of 2018 , total developing country debt stocks were $193 \%$ of their combined GDP. The pandemic could even worsen this rate. Furthermore, developing countries have to repay the sovereign debt of $\$ 2,7$ trillion by the end of 2021. Low and middle-income countries' share in this amount is $\$ 415$ billion in 2020 and $\$ 147$ billion in 2021. Due to the pandemic, the debt repayment of low- and middle-income developing countries will be so challenging. Lack of capital accumulation may even cause wide-spread debt crises unless sovereign debt repayments in poor developing countries are suspended (17) expects a massive income loss of firms and households as well as adverse effects on savings and income, increasing private debt stock due to COVID-19 in the following years.

Although all central banks initiated very effective monetary policies, these policies will not be solely effective to return to the pre-pandemic levels. Therefore, further fiscal stimulus is required (17).

\section{SECTORIAL REFLECTIONS OF THE PANDEMIC} COVID-19 pandemic has devastating effects on the sectors. In the next part, all sectors are analyzed separately. Agriculture Sector

Due to the pandemic, agricultural commodities dropped by $20 \%$. All of the countries around the world initiated protective measures. Self-isolation and quarantine measures had impacts on different products but mostly perishable products such as meat and vegetables. The delivery and transportation of products have difficulty in this process. Furthermore, many markets have shut down floor trading. This action impacted the ability to exchange commodities. In many countries, there was "panic buying" that caused shortages (33). The fall of commodity prices will be approximately $37 \%$ by the end of 2020 , with the major declines in metals and mineral productions. Comparing with the other commodities, there is less drop in agricultural commodity prices (17).

\section{Petroleum and Oil Sector}

Oil prices had been decreasing and volatile since 2016. The volatility of oil prices may deteriorate the macroeconomic parameters. For example, while volatility in oil prices increases inflation rates, it negatively affects the growth rates (34). Problematic situation worsened during the pandemic. Oil exporter countries were adversely affected by the COVID-19 pandemic. For the first time in history, the benchmark price for US crude oil, the West Texas Intermediate dropped to negative values. The pandemic led to a structural decline in the market for fossil fuels. Further precautions such as de-carbonization strategies, wider technological changes for renewable energy usage, and sustainable development policies also reversely affected the demand for oil. The pandemic also hit oil-exporting emerging countries for two reasons. First, the dependence of most of the oil-exporter emerging countries on a single commodity (resource extraction) for their export made them extremely fragile to market volatility. Despite the fact that most of the commoditydependent countries are in sub-Saharan Africa, in Algeria, 
Iran, Libya, and Iraq oil and gas have the majority share (approximately 60\%) of their total merchandise exports. Second, most of the oil-exporter countries were in a vulnerable position before the great shutdown. The pandemic caused further deterioration. More than half of the lower and middle-income developing countries dependent on natural resource exports are classified as "fragile". Those countries also have a similar strategic mistake. Most of these countries initiated wasteful infrastructure projects or overspend on consumption instead of investing in education or health services. Hence, during the pandemic, social and health services are weak and insufficient that caused vulnerable populations against the pandemic. In brief, these countries just focused on the extraction of resources rather than on improving the collective welfare (35).

\section{Tourism Sector}

The tourism industry is one of the two most affected sectors with the aviation sector due to travel restrictions and fully closed borders to take the pandemic spread under control. As illustrated in Figure 6, international tourist arrivals dropped by $70 \%$ during the January-October 2020 period. Since the Asia-Pacific region was the first geographic area that suffered the impact of the pandemic first, experienced a 79\% decrease in arrivals in January-August 2020. Africa and the Middle East both recorded a $69 \%$ drop this the given period. Europe had a $68 \%$ decline and the Americas $65 \%$. During the great shutdown between January and August 2020, 700 million less international touristic transportation recorded compared with the same period in the previous year. This loss represents $\$ 730$ billion in export revenue from international tourism. Another dramatic comparison is that tourism revenue loss under the pandemic is 8 times more than the loss in 2009, the year under the negative impact of the global financial crisis. In the summer months of 2020, some destinations started to render services within the Euro Area. Besides, domestic tourism shows positive signals of recovery in several markets such as China and Russia (36).

\section{Healthcare Sector}

The COVID-19 pandemic had great impacts on different sectors, but healthcare services are probably the most affected one. There was a sudden increase in the number of patients since it was very easy to be infected. Also, while hospitals had to deal with overcrowded emergency rooms and incentive care units, they also had to choose the surgeries according to their urgency. In each phase of the pandemic, there were different challenges that the health sector workers had to cope with. Actually, there were three

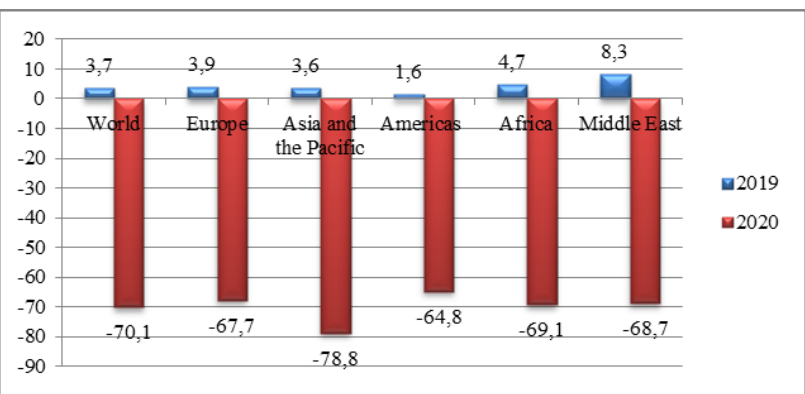

Figure 6. International tourist arrivals, 2019-2020 October (\% change). Source: UNWTO (36). phases of the pandemic. The first phase was the response phase. The characteristic of this phase is unpredictability. Due to uncertainties in the real and expected cases, disease progression and transmission as well as fatality rates and treatment alternatives urged the health care managers to operate in a crisis management model. They had to concentrate on how to manage the contingency, optimize supply and demand for healthcare services, arrange beds for inpatients and increase testing capacity. They also tried to improve the policies to fight the pandemic and find partners in the broader ecosystem to support each other. The second phase was the recovery phase. In this phase incidence rates became slower, case counts started to decline and organizations could improve back capacity and implement protocols to restore. In this phase, there are vaccination allocation models, new models for preparing and testing solutions. The third phase is thriving which represents embracing a renewed focus on health and wellbeing. Developing an effective vaccine, achieving herd immunity, improving an appropriate infrastructure to manage the disease through evidence-based treatments, safety measures and protocols are some of the characteristics of this phase. In this phase, health managers can monitor, detect, and prevent future risks to devise policies to manage expected lockdowns, and train employees to thrive in digital workplaces (37). Table 1 represents the 3 phases of pandemic management.

Within each phase, the pandemic caused not only the immediate needs of patient care but also required sources to finance extraordinary health expenditures. Finally, hospitals had to compromise cash flow and concern over capital expenditures (38).

\section{WHAT SHOULD BE DONE?}

Peter F. Drucker (1980) said that "The greatest danger in times of turbulence is not the turbulence itself, but to act with yesterday's logic". This explains how to manage the crisis in turbulent times. There is no doubt that the COVID-19 pandemic is global turbulence that humanity has to manage. Therefore instead of applying traditional methods, we need to find new and wise strategies to cope with the pandemic. It should be well-understood that combating the COVID-19 pandemic needs to think multidimensional. The problem should be managed multilateral by different parties such as health management, financing, governance, public and private sector support, and public opinion.

From the hospital management point of view, health managers should approach the problem from two sides: Managing demand and managing supply. Social distancing measures, travel restrictions, and lockdowns affected the demand. Hospital managements were also reorganized according to pandemic conditions. They had to decide which patients should stay at the hospital and which should be followed with alternative settlings such as home and telemedicine services. Some of the procedures were postponed for the patients' safety and having more room for urgent patients. And finally, using ICUs was also debated. How long patients (with or without COVID-19) should stay in the hospital and utilize an ICU was another critical decision for the policymakers and health managers. Table 2 shows the healthcare challenges, responses to these challenges, and policy recommendations to these challenges. 
Table 1. Phases of COVID-19 pandemic management. Source: Deloitte (37)

\begin{tabular}{|c|c|c|}
\hline Phase & Challenges & Opportunities \\
\hline Respond & $\begin{array}{l}\text { - Regulatory and policy barriers } \\
\text { - Lack of ecosystem cohesion }\end{array}$ & $\begin{array}{l}\text { - Acceleration of digital technologies } \\
\text { - Integration of data sources }\end{array}$ \\
\hline Recovery & $\begin{array}{l}\text { - Reactivity of proactivity } \\
\text { - Misunderstanding priorities } \\
\text { - Managing cybersecurity and ethical risks }\end{array}$ & $\begin{array}{l}\text { - Set a scale for the future } \\
\text { - Restore a sense of trust } \\
\text { - } \text { Focus on citizenship }\end{array}$ \\
\hline Thrive & $\begin{array}{l}\text { - Unpredicted risk mitigation } \\
\text { - Defaulting to the status quo } \\
\text { - Defining ongoing needs }\end{array}$ & $\begin{array}{l}\text { - Adopt to digitally restructured workplace } \\
\text { - Devise strategies to manage future outbreaks }\end{array}$ \\
\hline
\end{tabular}

Table 2. Healthcare challenges during the pandemic, responses, and policy recommendations. Source: Leite et al. (39)

\begin{tabular}{|c|c|c|}
\hline Challenge & Response & Recommendation \\
\hline $\begin{array}{l}\text { Low bed capacity } \\
\text { and ICU shortage }\end{array}$ & $\begin{array}{l}\text { - Redesigning flow and process } \\
\text { - move non-urgent appointments to telemedicine } \\
\text { - Delay non-urgent surgeries and treatments } \\
\text { - Giving more responsibilities to private hospitals }\end{array}$ & $\begin{array}{l}\text { Related to the increasing number of patients, } \\
\text { increasing need to have more bed capacity. } \\
\text { Therefore, strategic action plans should be } \\
\text { more proactive rather than reactive }\end{array}$ \\
\hline $\begin{array}{l}\text { Supply chain } \\
\text { constraints, lack of } \\
\text { medical device and } \\
\text { test kits and } \\
\text { resources }\end{array}$ & $\begin{array}{l}\text { - New plan for enlargement of inventory of key sources } \\
\text { - To overcome supply chain constraints, it may be a good } \\
\text { solution to work closer to supplier } \\
\text { - Cross-vertical cooperation between the sectors for key } \\
\text { requirements }\end{array}$ & $\begin{array}{l}\text { - Cooperation among the industries and } \\
\text { healthcare managers should have } \\
\text { inventories of key sources }\end{array}$ \\
\hline $\begin{array}{l}\text { Healthcare staff } \\
\text { shortage }\end{array}$ & $\begin{array}{l}\text { - Staff should be assigned to the high-priority areas and } \\
\text { departments } \\
\text { - Call the retired staff } \\
\text { - Medical and nursing early graduations } \\
\text { - Getting support from the social care sector and provide } \\
\text { healthcare at home }\end{array}$ & $\begin{array}{l}\text { - strategies and policies to increase the } \\
\text { number of healthcare workers }\end{array}$ \\
\hline $\begin{array}{l}\text { Increasing demand- } \\
\text { low capacity }\end{array}$ & $\begin{array}{l}\text { - demand and capacity management } \\
\text { - improve quality and safety } \\
\text { - reduce costs } \\
\end{array}$ & - try to increase capacity \\
\hline $\begin{array}{l}\text { A second or third } \\
\text { wave of infection or } \\
\text { increasing demand }\end{array}$ & $\begin{array}{l}\text { - } \text { applying suitable measures } \\
\text { - applying technology to have more coverage } \\
\text { - continue necessary services such as cancer care } \\
\text { - active collaboration between public, private and third sectors } \\
\text { - more investment in health services }\end{array}$ & $\begin{array}{l}\text { - to be ready for the second and third wave } \\
\text { of the pandemic and try to make more } \\
\text { investment in healthcare units such as } \\
\text { pandemic hospitals and ICUs. }\end{array}$ \\
\hline
\end{tabular}

It is a fact that uncertainty times will continue for a while. Members of the health ecosystem need to improve alternative policies to manage this vague process. The following policy recommendations may be key factors to achieve success in this process $(6,10)$ :

- To be aware of interdependencies between the systems and processes and taking precautions accordingly. In other words, if there is any change in one part of the system, that may generate unintended consequences. For example, if the treatment of a patient is postponed, the decision-makers should also take the future demand for future complications into account. Similarly, if the policymakers initiate curfew or restrictions for restaurants and social recreation places, there may be negative economic effects for these sectors. Therefore, policymakers and health managers should consider available resources, bottlenecks, and capabilities. That strategy also needs to be supported by the appropriate infrastructure and technological attempts such as mobile care units, telemedicine capabilities, treatment at home, etc.

- Forecasting sort-term demand: It may be a good strategy to forecast the short-term future demand in critical sectors such as healthcare, education, and food. Since the beginning of the pandemic, the countries could get enough data. By checking population density, daily testing rates, and social requirements, policymakers can forecast short-term demands.

- Managing supply-side and overcoming bottlenecks: Shortage of protective equipment and testing materials increase vulnerability to the pandemic. Producing or importing these materials are critical issues in both health services and working life. Therefore, bottlenecks should be overcome, and not only bottlenecks today but also the ones in the future should be identified. Thus, policymakers should make the forecasting and predict future bottlenecks and take precautions today.

- The highly interdependent supply chain may bring more bottlenecks and shifts in different sectors and departments.

- There has to be coordination and cooperation between the institutions and government entities. It should be noted that sharing both physical inventory and information is important.

- Innovating and learning in real-time.

- Focusing on information, fast decision-making, and learning from experiences. 
- Policy-makers should be convinced that the costeffectiveness of investments in primary healthcare is the best response to manage the COVID-19 spending. Particularly in poorer countries, it is necessary to invest in hospitals to increase ICU capacities and the number of ventilators. It is also very important to reach a broader population for medical screening and testing for COVID-19.

- In some of the developing counties, the legislation system is not strong enough and there may be corruption and waste. Therefore, those countries should be more careful in spending. For example, China, India, and the Philippines initiated institutions to control this spending.

- Civil authorities, local governments, and NGOs can be more proactive in supporting government services.

- Countries should get lessons from "beacon countries" that could build their own public health systems. The G20 and G7 countries can play vital roles in terms of leadership and support.

- Governments should ensure that health regimes are equitable.

- Countries should accept that health systems are important for global security.

Just like the "flattening the pandemic curve" which explains the deceleration of the transmission rate of the coronavirus in order to have enough hospital bed, ventilators, and enough time to find the cure, and patients can be properly treated, there can be a flattening curve of "economic infection". The basic objective of "flattening the curve" is to limit the economic damage of the inevitable output of lack of production during the economic shutdown and slowdown (40). To flatten "the economic infection curve", governments all over the world have announced fiscal measures to control their local economies. Hong Kong declared the largest package of measures amounting to $4 \%$ of GDP. European countries such as Italy, Spain, and the UK have initiated programs of about $1.5 \%$ of GDP, mostly targeting fiscal support for households and companies (Figure 7). Some of the measures are income subsidies for affected workers, debt repayment holidays, tax deferrals, social security deferrals, and state loans or credit guarantees for companies (1).

In the early months of the pandemic, some fiscal precautions were taken initially. The fiscal stabilizers such as increasing transfers were expected to be helpful to decrease the negative effect of support economic downturn on households and firms. Some measures were taken to

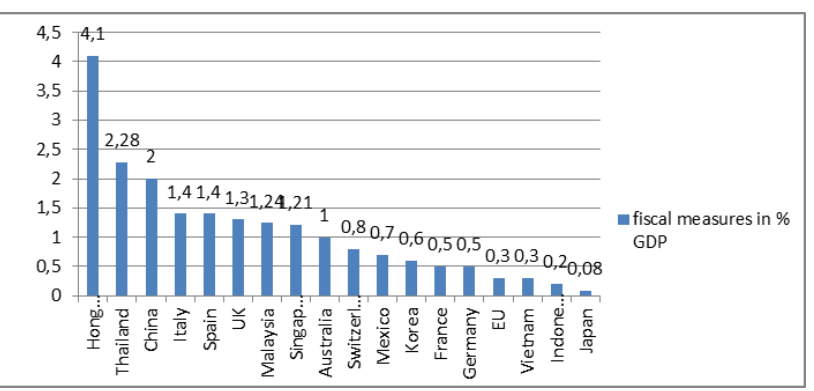

Figure 7. Announced fiscal measures of countries as \% of GDP. Source: Baldwin and di Mauro (1) ensure the workers' positions even during the quarantine period. Some governments provide rent, utilities, and insurance support to their citizens. To protect the firms, governments also provided some easiness waving tax, payroll payments, suspended loan payments and provided direct assistance. To support the financial system they also took some measures (40). A well-developed financial system can do much to mitigate the negative impacts of the pandemic on the real economy. By doing so, there may be a new operation with the environment and contribute to the recovery process. Lines of credit and credit guarantees may be helpful to provide additional financing to boost investment. Exporters and firms that are integrated with macro prudential exploit the export financing, factoring, and credit insurance supports. Financial sector measurements for financial stability should also be broad, transparent, and easy to understand. Macro prudential measures should provide capital space for banks to resume lending. Countries can initiate regulatory forbearance measures. Temporary, well-planned moratoriums on loan regulatory repayments are some of the economic measures. On the other hand, freezing classification and provisioning measures should be temporary and closely monitor second-round to avoid risks for banks and customers. Besides, central banks and economy authorities need to monitor financial soundness in terms of credit and liquidity trends more precisely. To prevent second round effects of the pandemic on the economy, insolvency, and financial safety frameworks will be critical. Some of the countries' central banks have already cut their policy rates and introduced liquidity support programs for banks through repo and swap transactions. Reserve requirements can be also applied for restructured and sound financial system (31). Besides, governments should provide liquidity in emerging markets to support trade finance flows and working capital expectations of the private sector. Also, the governments should support investments that can accelerate the recovery process. Also, the demand side of the financial, manufacturing, infrastructure, retail, and agriculture sectors should be supported (19).

However, many countries have already great economic problems, large budget deficits and it is hard for them to continue a long time of economic shutdown. Sharp declines in demand and supply should be handled. Households and businesses who are hit by a great shutdown should be supported more by cash transfers, wage subsidies, and tax relief to meet their needs and businesses to stay continue. For example, Italy extended tax deadlines for companies in deeply affected areas and broadened the wage supplementation fund to provide income support to laid-off workers. Korea initiated wage subsidies for SMEs and increased allowances for homecare and job seekers. China waived the social security contributions of businesses. Unemployment insurance duration can be extended, and governments can provide extra support for unwell workers or their caregivers to stay home without losing their jobs during the pandemic. VAT for SMEs was exempted for a certain period, the social contributions of the employees were exempted or halved, and municipalities are encouraged to waive urban land-use taxes and landlords to reduce or waive the rents. The cost of utilities was reduced. The government also subsidized the local and international airlines $(16,41)$. 
While providing policy suggestions, some specific features of the countries should be encountered. For example, oil-exporter developing countries should have a different model of support strategy. Since the late 2010s, there have been declining oil prices. This process has already negatively affected these countries since their economies are highly dependent on one single resource export. These countries need to get help to ease the burden of external public debt servicing. IMF and World Bank declared a "debt service standstill", a time-bound suspension of debt service payments for the least developed countries on 25 March 2020 (42). Similar action was taken by the finance ministers and central bankers of the G7 countries on 14 April 2020. This is a very critical strategy for these countries to have immediate liquidity. However, this is just a short-term solution since it does not waive the repayment of the principal debt. Therefore, efforts for the long run should be provided. The strategies should be launched as country-based. Until August 2020, no requests to private creditors have been made. Besides, private creditors can be applied.

Broader monetary policies such as policy rate cuts and asset purchases can be supportive in the financial sector since there is an increased risk of sizable constraints in financial conditions. Furthermore, the policies and actions of large central banks may generate favorable spillover effects for vulnerable countries. In addition, broad fiscal policies consistent with available fiscal space can support lifting aggregate demand. Business operation normalization will be more effective in this process. Besides, the international community should support countries with limited health capacity. IMF declared support to vulnerable low-income and emerging countries with an amount of up to $\$ 50$ billion (16).

Different from the other countries, China implemented industry policies focusing on large infrastructure investment projects and supply chains. To expand domestic demand, by the participation of many ministries, the government tried to stimulate infrastructure investments. Specific projects those are related to energy, IT, and transportation have been initiated and financed by special local government bonds (41). China also increased foreign trade credits, extend debt rollovers, and loan payments for SMEs. Commercial insurance companies were also encouraged to provide short-term credit insurance and lower fees for trading firms (41).

And finally, for successful management, political leadership is also important (43). Admitting and learning from mistakes and improvement and re-arranging macroeconomic policies depending on the current improvements are critical in managing the process. The timing is important. Doing write policies at the right time is more effective than time lagging policies. Economic supports and measures are accurately needed during crisis periods. Strict health policies can be useful to slow down the spread of the pandemic. These protections provide a larger part of the population unexposed to the disease. Hence, if governments continue the strict containment measures for a longer time, the spread of pandemics can be taken under control. China and Taiwan applied such strategies (40).

There are also new trends for real sector support for the post-pandemic period. Table 3 shows these trends.

\section{CONCLUSION}

The COVID-19 pandemic has been having devastating effects both on advanced and emerging economies. Not only healthcare services but also almost all other sectors are affected by the pandemic. Although there has been more than a year passed since the pandemic had been detected, there is neither a proper treatment nor a perfect vaccination to slow down its spread. This dark screen also affects the macroeconomic performances of the countries. Since there is interdependence between healthcare services and economic activities, both of them affect each other. While lockdowns and curfews could not stop the pandemic, opening the economic activities may provide a perfect incubation for the virus to be spread. This dilemma seems to continue at least one more year. Vaccinating whole societies can be helpful to break up this vicious circle. Meanwhile, aside from traditional macro prudential policies, some alternative policies could be initiated. Particularly health managers and economy authorities should work together to overcome the pandemic period. All parties should be aware of interdependence. Authorities should forecast the short-term future demand in critical sectors such as healthcare, education, and food. Besides, an interdependent supply chain may cause

Table 3. New trends in real sector in the post-COVID-19 period. Source: IFC (44).

\begin{tabular}{|c|c|}
\hline Trend & Key features \\
\hline $\begin{array}{l}\text { The global supply } \\
\text { chain shifts towards } \\
\text { localization and } \\
\text { diversification }\end{array}$ & $\begin{array}{l}\text { - The strategic sectors such as healthcare, personal protective staff, food packaging, etc. get more intention. } \\
\text { For the products that need complex value chains such as different processes of production in different } \\
\text { countries, companies diversify their supplier base in order to have flexible sources for production. } \\
\text { - This process is good for emerging countries such as Turkey, Morocco, and Mexico which have suitable } \\
\text { capacities in certain sub-sectors. As an example, Chinese manufacturing shifted to Africa for local } \\
\text { manufacturing even before the pandemic. No doubt that the pandemic process will accelerate this process. }\end{array}$ \\
\hline $\begin{array}{l}\text { Increasing digital } \\
\text { transformation }\end{array}$ & $\begin{array}{l}\text { - More digital applications are needed in business in the middle and long run. The technological application } \\
\text { will be more important for efficiency and competitiveness. } \\
\text { - More interest in digital platforms and innovative digital business models. Digital platforms will provide } \\
\text { stronger supply chains by reducing the necessity of intermediaries. This model is beneficial for also price } \\
\text { transparency and market-wide cost reduction. } \\
\text { - More digital consumers and teleservices both in food purchases and health services. }\end{array}$ \\
\hline $\begin{array}{l}\text { More interest in } \\
\text { impact-oriented } \\
\text { investments }\end{array}$ & $\begin{array}{l}\text { - Health and logistic sectors get more interest during and after the pandemic period. } \\
\text { - More economic and environmental concerns. } \\
\text { - More private sector funding in education, health investments }\end{array}$ \\
\hline
\end{tabular}


unexpected bottlenecks in sectors. Also, innovative technologies should be courageous both for improving new techniques for working and finding alternative treatment models. There has to be international cooperation among all countries to cope with the pandemic. NGOs and international prestigious institutions should also take part to fight the pandemic. International coordination and global cooperation are very important for fighting both economic and coronavirus infections.

Ethics Committee Approval: Since our study was a review, ethics committee approval was not required.

Conflict of Interest: None declared by the authors.

Financial Disclosure: None declared by the authors.

Acknowledgements: None declared by the authors.

Author Contributions: Idea/Concept: NDÇ, AG, SE; Design: NDÇ, AG, SE; Data Collection/Processing: NDÇ, AG, SE; Analysis/Interpretation: NDÇ, AG, SE; Literature Review: NDÇ, AG, SE; Drafting/Writing: NDÇ, AG, SE; Critical Review: NDÇ, AG, SE.

\section{REFERENCES}

1. Baldwin R, di Mauro BW. Introduction. In: Baldwin R, di Mauro BW, editors. Mitigating the COVID economic crisis: Act fast and do whatever it takes. London, UK: CEPR Press; 2020. p.1-10.

2. Hellowell M, Myburgh A, Sjoblom M, Gurazada S, Clarke D. COVID-19 and the collapse of the private health sector: A threat to countries' response efforts and the future of health systems strengthening? Geneva: WHO; 2020.

3. Verwey M. Foreword. In: European Commission. European economic forecast, spring 2020. European Economy Institutional Papers 125. Brussels: European Commissions; 2020.

4. Lagarde C. Live webinar speech on youth dialogue for the European Youth Event 2020, 27 May 2020. Available from: https://www.youtube.com/watch?v=Otuc4lSqjAI

5. imf.org [Internet]. International Monetary Fund. A crisis like no other. Annual report 2020, a year like no other. September 15, 2020. Available from: https://www.imf.org/external/pubs/ft/ar/2020/eng/spot light/covid-19/

6. odi.org [Internet]. Samman E. Towards universal health systems in the COVID-19 era, opportunities and threats. Overseas Development Institute, May 19, 2020. Available from: https://odi.org/en/publications/ towards-universal-health-systems-in-the-covid-19era-opportunities-and-threats/

7. cgdev.org [Internet]. Evans D, Over M. The economic impact of COVID-19 in low- and middle-income countries. Centre for Global Development, March 12 2020. Available from: https://www.cgdev.org/blog/ economic-impact-covid-19-low-and-middle-incomecountries

8. O'Hanlon B, Hellowell M. Enabling the private health sector in the national response to COVID-19: Six current policy challenges. Geneva: WHO; 2020.
9. cgdev.org [Internet]. Sembene D. Is Africa wasting the pandemic-induced economic crisis? Center for Global Development, January 27, 2021. Available from: https://www.cgdev.org/blog/africa-wasting-pandemicinduced-economic-crisis

10. hbr.org [Internet]. Bohmer RMJ, Pisano GP, Sadun R, Tsai TC. How hospitals can manage supply shortages as demand surges. Harvard Business Review, April 3, 2020. Available from: https://hbr.org/2020/04/howhospitals-can-manage-supply-shortages-as-demandsurges

11. cgdev.org [Internet]. Gupta S, Jalles JT. Tax reforms in developing countries in an era of COVID-19. Center for Global Development, March 2, 2021. Available from: https://www.cgdev.org/blog/tax-reformsdeveloping-countries-era-covid-19

12. squirepattonboggs.com [Internet]. Tully I, Sabelli D, Vismara F. COVID-19 Impact on the Italian healthcare sector. Squire Patton Boggs, April 17, 2020. Available from: https://www.squirepattonboggs.com/en/insights/ publications/2020/04/covid-19-impact-on-the-italianhealthcare-sector

13.cgdev.org [Internet]. Glassman A. Protecting and transforming social spending through the COVID-19 crisis. Center for Global Development, February 25, 2021. Available from: https://www.cgdev.org/event/ protecting-and-transforming-social-spending-throughcovid-19-crisis

14. marketplace.org [Internet]. Adams K. Will the pandemic mean higher health care costs in the future? Marketplace, March 31, 2020. Available from: https://www.marketplace.org/2020/03/31/will-thepandemic-mean-higher-health-care-costs-in-the-future/

15. Cavallo A. Inflation with COVID consumption baskets. NBER Working Papers. 2020:27352. doi: $10.3386 / \mathrm{w} 27352$

16. Gopinath, G. Limiting the economic fallout of the coronavirus with large targeted policies. In: Baldwin R, di Mauro BW, editors. Mitigating the COVID economic crisis: Act fast and do whatever it takes. London, UK: CEPR Press; 2020. p.41-8.

17. United Nations Conference on Trade and Development. The COVID-19 shock to developing countries: Towards a "whatever it takes" programme for the two-thirds of the world's population being left behind. Trade and Development Report Update, UNCTAD/GDS/INF/2020/2, Geneva: UNCTAD; 2020.

18. Wyplosz C. The Euro area after COVID-19. Policy Department for Economic, Scientific and Quality of Life Policies. Monetary Dialogue Papers, November 2020. Luxembourg: European Parliament; 2020.

19. ifc.org [Internet]. International Finance Corporation. COVID-19 economic impact: Europe and Central Asia. International Finance Corporation, May 2020. Available from: https://www.ifc.org/wps/wcm/connect/ publications_ext_content/ifc_external_publication_site/ publications_listing_page/covid-19-response-brief-eca

20. ifc.org [Internet]. International Finance Corporation. COVID-19 economic impact: Middle East and North Africa. International Finance Corporation, May 2020. Available from: https://www.ifc.org/wps/wcm/connect/ publications_ext_content/ifc_external_publication_site/p ublications_listing_page/covid-19-response-brief-mena 
21. European Commission. European economic forecast, spring 2020. European Economy Institutional Papers 125. Brussels: European Commissions; 2020.

22. cgdev.org [Internet]. Plant M, Andrews D. Enabling substantial IMF lending to low-income countries for the recovery. Center for Global Development, February 9, 2021. Available from: https://www.cgdev.org/blog/enabling-substantial-imflending-low-income-countries-recovery

23. cgdev.org [Internet]. Sembene D. How an allocation of IMF SDRs to Africa could be supported by a multilateral reallocation initiative. Center for Global Development, February 23, 2021. Available from: https://www.cgdev.org/blog/how-allocation-imf-sdrs-africacould-be-supported-multilateral-reallocation-initiative

24. ilo.org [Internet]. International Labour Organization. ILO Monitor: COVID-19 and the world of work. 2nd edition. Updated estimates and analysis, April 7, 2020. Available from: https://www.ilo.org/global/about-theilo/WCMS_740877/lang--ja/index.htm

25. Gehrke B, Hochmuth B. Counteracting unemployment in crises: Non-linear effects of short-time work policy. Scand J Econ. 2021;123(1):144-83

26. Pierri N, Timmer Y. IT shields: Technology adoption and economic resilience during the COVID-19 pandemic. IMF Working Papers. 2020:20/208. Available from: https://www.imf.org/en/Publications/ WP/Issues/2020/09/25/IT-Shields-TechnologyAdoption-and-Economic-Resilience-during-theCOVID-19-Pandemic-49754

27. princeton.edu [Internet]. Brunnermeier M, Merkel S, Payne J, Sannikov Y. COVID-19: Inflation and deflation pressures. September 15, 2020. Available from: https://scholar.princeton.edu/sites/default/files/ merkel/files/covid19inflationdisinflation.pdf

28. Reserve Bank of Australia. Chapter 5, Inflation. In: Statement on Monetary Policy, May 2020. Australia: RBA; 2020. p.77-84.

29. insightinvestment.com [Internet]. Insight Investment. COVID-19 is likely to end the inflation lockdown, May 2020. Available from: https://www.insightinvestment. com/globalassets/documents/recent-thinking/covid19-is-likely-to-end-the-inflation-lockdown.pdf

30. Erdoğan S, Yıldırım DÇ, Gedikli A. Dynamics and determinants of inflation during the COVID-19 pandemic period in European countries: A spatial panel data analysis. Duzce Med J. 2020;22(S1):61-7.

31. Schiffbauer MT, World Bank. The economic and social impact of COVID-19. Western Balkans Regular Economic Report, No. 17, Spring 2020. doi: $10.1596 / 33670$

32. worldbank.org [Internet]. The World Bank. Debt Burden of Least Developed Countries continues to climb to a record $\$ 744$ billion in 2019 . Press Release No. 2021/037/DEC, October 12, 2020. Available from: https://www.worldbank.org/en/news/press-release/ 2020/10/12/debt-burden-of-least-developed-countriescontinues-to-climb-to-a-record-744-billion-in-2019

33. Nicola M, Alsafi Z, Sohrabi C, Kerwan A, Al-Jabir A, Iosifidis $\mathrm{C}$, et al. The socio-economic implications of the coronavirus pandemic (COVID-19): A review. Int J Surg. 2020;78:185-93.
34. Erdoğan S, Çevik Eİ, Gedikli A. The effect of the oil prices volatility on economic growth and inflation: the case of GCC countries. Kafkas Üniversity Economics and Administrative Sciences Faculty, KAUJEASF. 2020;11(21):306-30.

35. oecd.org [Internet]. Organisation for Economic Cooperation and Development. The impact of coronavirus (COVID-19) and the global oil price shock on the fiscal position of oil-exporting developing countries. OECD Policy Responses to Coronavirus (COVID-19), September 30, 2020. Available from: https://www.oecd.org/coronavirus/policy-

responses/the-impact-of-coronavirus-covid-19-andthe-global-oil-price-shock-on-the-fiscal-position-ofoil-exporting-developing-countries-8bafbd95/

36. The World Tourism Organization (UNWTO). International travel plunges $70 \%$ in the first eight months of 2020. World Tourism Barometer. 2020;18(6):1-36.

37. deloitte.com [Internet]. Deloitte. COVID-19: Accelerating the evolution of the health sector. How to respond, recover, and thrive--then do it again. Available from: https://www2.deloitte.com/ca/en/ pages/public-sector/articles/accelerating-evolution-ofhealth-sector.html

38. fticonsulting.com [Internet]. FTI Consulting. Impact of the coronavirus pandemic on healthcare construction projects. Forensic \& Litigation Consulting | Construction, May 21, 2020. Available from: https://www.fticonsulting.com/insights/articles/impactcoronavirus-pandemic-healthcare-construction-projects

39. Leite H, Lindsay C, Kumar M. COVID-19 outbreak: implications on healthcare operations. The TQM Journal. 2021;33(1):247-56.

40. Gourinchas PO. Flattening the pandemic and recession curves. In: Baldwin R, di Mauro BW, editors. Mitigating the COVID economic crisis: Act fast and do whatever it takes. London, UK: CEPR Press; 2020. p.31-40.

41. Huang Y, Lin C, Wang P, Xu Z. Saving Chia from the coronavirus and economic meltdown: Experiences and lessons. In: Baldwin R, di Mauro BW, editors. Mitigating the COVID economic crisis: Act fast and do whatever it takes. London, UK: CEPR Press; 2020. p.77-92.

42. imf.org [Internet]. International Monetary Fund. Joint Statement World Bank Group and IMF call to action on debt of IDA countries. March 25, 2020. Available from: https://www.imf.org/en/News/Articles/2020/03/ 25/pr20103-joint-statement-world-bank-group-andimf-call-to-action-on-debt-of-ida-countries

43. Quah D. Singapore's policy response to COVID-19. In: Baldwin R, di Mauro BW, editors. Mitigating the COVID economic crisis: Act fast and do whatever it takes. London, UK: CEPR Press; 2020. p.103-12.

44. ifc.org [Internet]. International Finance Corporation. Impacts of the COVID-19 crisis on private equity funds in emerging markets. International Finance Corporation, 2020. Available from: https://www.ifc. org/wps/wcm/connect/publications_ext_content/ifc_e xternal_publication_site/publications_listing_page/co vid-19-impact-funds-emerging-markets 